\title{
The role of perceived green marketing and brand equity on green purchasing decision
}

\author{
HASNA SANIDEWI ${ }^{1}$ and ERISTIA LIDIA PARAMITA ${ }^{1}$ \\ ${ }^{1}$ Department of Management, Faculty of Ecomonics and Business, Satya Wacana Christian University, Indonesia
}

\begin{abstract}
The purpose of this study is to describe the role of perceived green marketing and brand equity on customers green purchasing decision in Indonesia. We conducted qualitative research using five informants who are customers of The Body Shop Indonesia, one of the companies implementing green marketing. The primary data was collected through the interviews, observations, and supported documents, as triangulation. The collected data was filtered and categorized to have a clear analysis. The results were shown that the informants perceived The Body Shop's green marketing as a respectable action to reduce the negative impact of the firms' business activities. Green marketing has developed and influenced The Body Shop brand positively. It leads the informants to insert their environmental consideration in their purchasing decision.
\end{abstract}

\section{INTRODUCTION}

Being green is claimed to be an important consideration for human and business environment. Firms are not only focused on profit, but also concern on environmental and sustainability issues as their business parts (Boztepe, 2012). The Ministry of Environment of Indonesia stated that "green" is growing as a trend, which is waving the daily activities of consumers. The terms "green label", "green products", "green business", and so on are trying to represent the excitement of being "green". These "green" terms engage with environmental management which hasturned into market demands. It encourages several multinational companies in Indonesia such as The Body Shop, Procter and Gambler, Loblow International Merchants, and The 3M Company to fulfil the green demand. They were given a predicate as "green business" by The Ministry of Environment of Indonesia. Thus, the green movement has progressed from a trend into a business approach (Maheshwari, 2014).

For the past few years, consumers started to give more attention in green products and purchased products with green attributes (Rakhsha \& Majidazar, 2011). Among several product categories, this study focuses on the beauty product category. Describing green consumers through beauty products is supported by two reasons. First, beauty products are considered as personal necessities. Second, beauty products reveal the consumers' purchasing habits. It reveals a unique discussion about the greenness and the aesthetics (Todd, 2004). The feeling of being green through natural beauty products entered Indonesia through The Body Shop since 1992. The Body Shop continuously serves its consumers by the sense of lovingness in nature. The concern of environment welfare and sustainability are parts of its business. The commitment of "Enrich Not Exploit. It is in Our Hands." has been successfully brought The Body Shop as the green business.

The products which are highly engaged with the customers are the products with high brand equity. It might be affected by the marketing actions of the brand itself (Yoo et al., 2000). Applying green marketing clamied as an alternative way for raising the intangible brand equity product brand and obtain competitive advantage product brand (Arseculeratne \& Yazdanifard, 2014; Chang \& Chen, 2014; Nazari et al., 2015). The study of Carrigan and Attalla (2001) revealed that all informants pointed out The Body Shop when they were asked about the most responsible firm. Customers' emotional 
connection with a brand and strong preferences for the brand create the customers' loyalty (Chang \& Fong, 2010). Beside The Body Shop, numerous international brands are also competing to attract consumers all over the world by conveying their green practices. To live on the unpredictable demand, an international firm should has a good management in global setting (Sinnappan \& Rahman, 2011; Buil et al., 2013). When the brand equity is achieved, the consumers are willing to pay the premium price and loyal to the brand (Yoo et al., 2000; Delafrooz et al., 2014).

Previous studies has been expressed the green practices in different statements. Delafrooz at al. (2014) confirmed that several consumers were not influenced by green marketing. The high price of green products and the availability of the green products become consumers' concern when they decide to purchase (Young et al., 2010; Awan \& Wamiq , 2016). It may lead to the low purchase of green products (Chan R. Y., 2001). Although consumers decided to purchase green products, environmental motive is not the main reason. It might be influenced by personal motive, social motive, and economic motive (Ottman et al., 2006). Based on the aforementioned studies, this study focuses on describing the green marketing of The Body Shop related with its brand equity and green purchasing decision of its customers. There are three questions that need to be answered and understood deeper regarding to the issues:(1) How do the customers perceiveThe Body Shop's green marketing? (2) How does the green marketing affect brand equity of The Body Shop? (3) Why do the customers decide to purchase The Body Shop productsas the green products? This study attempts to describe the role of the green marketing, brand equity, and green purchasing decision of The Body Shop's customers in deeper understanding.

\section{LITERATURE REVIEW AND HYPOTHESES DEVELOPMENT}

\section{The understanding of green marketing}

The term "green marketing" was firstly introduced by The American Marketing Association (AMA) through its first workshop "Ecological Marketing" to examine the marketing's impact on the natural environment (Delafrooz et al., 2014). For the last two decades, green marketing emerged and became a prominent topic to be discussed (Todd, 2004; Peattie \& Crane, 2005; Ottman et al., 2006; Haytko \& Matulich, 2008; Banyte et al., 2010; Rakhsha \& Majidazar, 2011; Arseculeratne \& Yazdanifard, 2014). Previously, Polonsky (1994) has defined green marketing as the overall activities which facilitate human needs and wants, with minimum negative impacts on the natural environment. In other words, green marketing is a practicewhich considers the environment sustainability from the time of production process up to advertisement process. The environment quality improvement and the customers' satisfaction are two objectives that must be achieved in doing green marketing (Ottman et al., 2006). In order to achieve those two objectives, marketers which imply green marketing should give proper information about their green activities to make the consumers get the information clearly (Sinnappan \& Rahman, 2011).

Consumers who care with the environment are expected to be aware of and understand about the green attributes of the product (Rahbar \& Wahid, 2011; Delafroozet al., 2014). The implementation of green marketing should be followed by its integration and communication about the importance of being green (Maheshwari, 2014). There are three tools of green marketing which known as the means to communicating the environmental practices of a firm: eco-label, eco-brand, and environmental advertisement (Rahbar \& Wahid, 2011; Delafroozet al., 2014).

\section{The three tools of green marketing}

There are three tools of green marketing, which are:

\section{a. Eco-label}

A visible label in product packaging is the essential means to convince the consumers (Uusitalo \& Oksanen, 2004). Firms use ecolabel as information provider about their green practices (D'Souza et al., 2006). For instance, NYX cosmetics put an addition label "Cruelty Free" on its products to convince their customers that they do not violate animals or environment during their production. Eco-labels attractconsumers to do the environmental contribution by doing green purchasing decision (Rashid, 2009). An information label which can completely persuade consumers is known as a perfect 
label. While an information label which only partially persuade consumers is known as an imperfect label (Bonroy \& Constantos, 2008). b. Eco-brand

Eco-brand is the combination of symbols and other designs that conveys the environmental harmless products (Delafrooz et al., 2014). Orsato (2006) stated that eco-branding acts as one of the competitive environmental strategies. Eco-brands have emerged in various kinds of product categories such as food, cosmetics, cleaning products, and product packaging (Peattie \& Crane, 2005).

c. Environmental advertisement

Advertising is one of marketing variables which mostly attractive (Buil et al., 2013). Environmental advertisement is advertisement which contains environmentalaspects. The purpose of environmental advertisement is to influence and encourage consumers to purchase product by considering the environmental issues. Therefore, it will guide consumers for not harming the environment and to be aware of the positive impact in purchasing green products (Rahbar \& Wahid, 2011). To increase the attractiveness, firms should be able to decide on what environmental issues will be featured in the advertisement (Chan \& Han, 2014). The strong environmental advertisement leads to the specific and acceptable of its greenness (Leonidou et al., 2011; Leonidou et al., 2014).In Indonesia, mineral water brands such as Aqua and Ades, express their environmental advertisement by squeezing the empty plastic bottles. The purpose is to avoid the reuse of plastic bottles.

\section{Brand equity}

The influence of brands on consumers' purchasing decision was stated by Rahbar and Wahid (2013) as brand equity.

Aaker (1996) suggested that there are ten dimensions which are used to measure brand equity, called "The Brand Equity Ten". In addition, he also suggested that the good management of the ten dimensions will lead to the health brand equity.

\section{Green purchasing decision}

High consumption in a globalization era may affect human environment negatively (Sinnappan \& Rahman, 2011). Air pollution, animal extinction and scarcity of natural resources are the examples of devastated environment. Thus, consumers are considering more about the ethical practices of a firm (Shaw et al., 2005; Carrington et al., 2014). One of ethical approaches is through environmental or green action (Carrington et al., 2010). Green purchasing decision means inserting the environmental features to product price and performance when making purchase decisions (Vazifehdoust et al., 2013). Consumers' concern on the future generations, environmental protection, and responsibility encourage the marketers to understand the consumers' preferences toward green products (Banyte et al., 2012).

The consumers who care for the environmental issues tend to consume the green products (Sinnappan \& Rahman, 2011). The examples of products with the green attributes are organic certified food products, eco-friendly sanitary products, cruelty free body care products, and biodegradable product waste (Vazifehdoust et al., 2013; Awan \& Wamiq , 2016). Price, quality, and brand assumed to be the most considered elements when making green purchasing decision (Gan et al., 2008). Consequently, the integration between price, quality, brand, and high performance of the products itself must be in a well-managed to drive the consumers into their actual purchasing decision (Sinnappan \& Rahman, 2011). Since price is the major element of products (Yoo et al., 2000; Young et al., 2010), the green consumers' response towards green marketing is identified by their willingness to pay higher price for environmentally friendly products compared to the regular products (Haytko and Matulich, 2008; Banyte et al., 2010).

Another influence of green purchasing decision of consumers is demographic profiles of consumers (Laroche et al., 2001; Gan et al., 2008; Sinnappan \& Rahman, 2011; Kaufmann et al., 2012). Gender, marital status, and number of children living at home influence consumers to spend more money for green products. While age, education, income, and work status do not influence consumers to spend more on green products (Laroche et al., 2001). Some aspects are differently stated byGan et al. (2008). Theybelieved that age, education, and marital status positively influence green purchasing decision. Gender, income, ethnic, and number of children, do not have influence on green purchasing decision. Consumers may reflect their behavior 
differently in different product categories (Carrington et al., 2014).

Unfortunately, not all consumers influenced by green marketing strongly (Delafrooz et al., 2014). The phenomenoncreates assumption that driving the consumers into actual green purchasing decision is not as easy as it is claimed. It can be assumed that the consumers' understanding and consumers' trust toward green practices are needed in order to inform the consumers better (Peattie \& Crane, 2005). Summarizing on what have been found in previous studies, there are several antecedents that need to be pointed out regarding the green purchasing decision of the consumers.

\section{- Personal motives}

Better product performance and product enjoymentof the green products described the individuals' desires to purchase the green products(Ottman et al., 2006).

\section{- Economic motives}

Assumption on longer-term money savings in products with energy efficiency (Ottman et al., 2006) and the affordable price of the green products support the green purchasing decision of consumers (Young et al., 2010).

- Social motives

The innovation on green products reveals a symbol for being smart, socially responsible, and prestige (Ottman et al., 2006).

- Situational factor

Different time consumption, living movement of the consumers, and the availability of the green products are significantly affect consumers decision to purchase green products (Young et al., 2010).

Since the green purchasing decision is personal (Todd, 2004), the influence of each antecedents may differ on each individual.

\section{METHODS}

\section{Data sample}

The population of this study is The Body Shop customers in Indonesia. In qualitative study, the samples are not necessarily representing the population. The amounts of informants are relatively small, to filter as many information as possible from various informants and constructions (Moleong, 2010).
In concerning the efficiency of time, credible data, and the possibility of gathering information, this study applied judgmental sample. The criterion of informants for this study referred to the combination of Laroche et al. (2001) and Gan et al. (2008) demographic segmentation. The informants of this study were required to be women who lived in Salatiga, working, in the range age of 25-40 years old (adult age), The Body Shop's customers who bought the products directly to the stores, and use The Body Shop productsregularly and continuously for at least five years.

\section{Data collection and analysis}

Moleong (2010) stated that the use of triangulation is important to assured the data validity. Triangulation collects information from three different sources. The study towards The Body Shop consumers applied triangulation through interviews, direct observation, and field documentation.

Research technique acts as an important part in research. The triangulation method was designed to gain as many information as possible.

Interview

Profound conversations were completed in three key informants who have been chosen according to the criterions. There were 22 questions which needed to be answered in this study. Seven questions were used in answering resarch question number one, nine questions were for research question noumber two, and six questions were using to answer the research question number three. All of the question guidelines were derived from the measurement elements on each variable.

\section{Documents}

Voice records and pictures acted as important documents to support the interview. The voice recordings were taken during the interviews.

- Participant observation

In order to match on the informants' actual behavior, this study needs to do observation. The informants were observed through their ways to access The Body Shop's information and The Body Shop's stores, and also their engagement with The Body Shop products. The duration was depending on the willingness of the informants. 
Table 1.

Informants' Characteristics

\begin{tabular}{|c|c|c|c|c|c|}
\hline No. & Informants & Age & Occupation & $\begin{array}{c}\text { Use } \\
\text { Duration }\end{array}$ & $\begin{array}{l}\text { Budget spending } \\
\text { ( } \pm \text { per } 2 \text { months) }\end{array}$ \\
\hline 1 & Informant $A$ & 29 y.o. & $\begin{array}{c}\text { Director of PT KOIN } \\
\text { Garment }\end{array}$ & 9 years & $>$ Rp 500.000,- \\
\hline 2 & Informant B & 27 y.o. & $\begin{array}{c}\text { Medical Representative at } \\
\text { Bayer }\end{array}$ & 8 years & \pm Rp 500.000,- \\
\hline 3 & Informant C & 35 у.о. & $\begin{array}{l}\text { Librarian at Mountainview } \\
\text { International School }\end{array}$ & 10 years & Any amount \\
\hline 4 & Informant D & 35 y.o. & $\begin{array}{c}\text { Entertainer (MC and } \\
\text { Singer) }\end{array}$ & $>5$ years & $\pm \mathrm{Rp} 500.000,-$ \\
\hline 5 & Informant E & 38 y.o. & $\begin{array}{c}\text { Owner of CV Berkah Mulia } \\
\text { Garment }\end{array}$ & $>5$ years & $>$ Rp 1.000.000,- \\
\hline
\end{tabular}

\section{RESULTS AND DISCUSSION}

The data collection of this study was done in one month (February 8 - March 8,2017 ), in Salatiga. The result analysis of this study is constructed by the interview and observationtowards five informants, in relation with green marketing, brand equity, and green purchasing decision toward The Body Shop products. The five informants were all women, living in Salatiga, working, and adults.

Table 1 shows the informants' characteristics related to their age, their occupation, their use duration of The Body Shop products, and the amount of money that they spent for The Body Shop products. The age range of the informants is $27-38$ years old. All of the informants have been engaged with The Body Shop products for more than five years, in regular and continuous consumption. There are two informants who work in the industry field, which are Informant $A$ and Informant $E$. Informant B work in the health field, Informant $C$ in the administration field, and Informant D in the entertainment field. The Body Shop attracts the informants, as it is claimed to be cruelty free, natural, and fair trade products. In purchasing The Body Shop products, they are willing to spend in range of $\mathrm{Rp}$ $500.000,00$ - Rp 1.000.000,00 and even in any amount, for more or less every two months.

\section{The informants' perception on The Body Shop's green marketing}

The awareness of environmental issue shows that there has been an emotional bond between customers and The Body Shop as stated by Chang and Fong (2010) and Iwan
(2013). Related with the informants' characteristics, their direct visit to the stores within more than five years allowed them to value the green marketing of The Body Shop. As The Body Shop customers, the informants have been familiar with the green marketing term. Mainly, the informants perceived the green marketing as the means to solve the environment problems. The green practices of The Body Shop are expected to make the environment condition are improved.

Similar to what Rahbar and Wahid (2013) and Delafrooz et al. (2014) found in their study, this study also found that the informants perceived green marketing through the visible product attributes of The Body Shop. The Body Shop's eco-label, ecobrand, and environmental advertisement performed as credible tools to deliver its green message. The eco-label has strongly convinced the informants about The Body Shop green practices (Uusitalo \& Oksanen, 2004; D'Souza et al., 2006). It was shown through Informant $C$ and Informant $D$ who saw 'no animal testing' as part of The Body Shop's green marketing.

" $E$... because at the first time, first time I purchased The Body Shop, there was 'no animal testing' label behind the products, and it attracted me." - Informant $\mathrm{C}$

"Identify its [The Body Shop] green marketing, through the label first. I see the label, there is 'no animal testing' label, then e... they use natural ingredients." - Informant D

The proper and clear information have helped the informants to understand The Body Shop's green marketing (Sinnappan \& Rahman, 2011). Simple words and visible information would influence the informants 
effectively. The direct visit of the informants to The Body Shop stores is important because the labels, pamphlets, and campaigns will be placed at the stores. Ultimately, the success of the green marketing can be achieved. Informant $D$ claimed eco-label as the easiest means to inform her about the green practices.

"It [eco-label] is the easiest one. As an ordinary people, it is impossible for us to intensely ask the beauty assistant about 'what are the ingredients? Is this natural?'. We certainly know that." Informant D

The green marketing tools also educated the informants to respect the environment. They believe that they can give positive impacts by purchasing The Body Shop products (Rahbar \& Wahid, 2011). It shows that the environment quality improvement and the customers' satisfaction are achieved by doing green marketing (Ottman et al., 2006). By integrating the producers and consumers, the green marketing can successfully help the environment (Arseculeratne \& Yazdanifard, 2014). Informant A realize that using The Body Shop products are not only affects her skin and surrounding environment, but also affects the other nations. It means that there is integration between The Body Shop and Informant A.

"For example, Africa is the coconut producer. They [The Body Shop] made it as their theme. They show, oh yeah e... what to say, bringing the 'save our nature' theme is by using the natural product, we perhaps give a positive impact for people, for environment, or the country itself." - Informant A

Based on the aforementioned discussions, it reveals the relation between two variables. Figure 1 below shows the causality of ecolabel and environmental knowledge of the informants.

Figure 1. Proposed model for eco-label and environmental knowledge

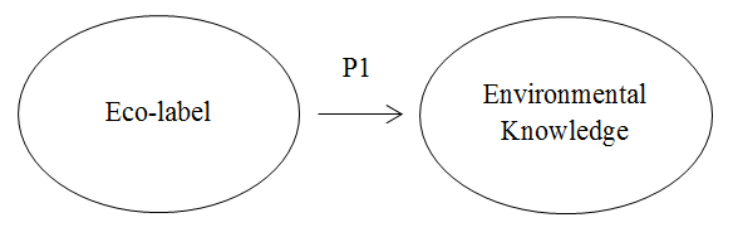

In specific, eco-label is one of the green marketing tools which were suggested by Rahbar and Wahid (2013) and Delafrooz et al. (2014). The green messages which were delivered through eco-label, such as 'no animal testing' label, help the informants to understand on how important the environment is. Therefore, this study proposes that the eco-labels on The Body Shop products influence the environmental knowledge of the informants.

In practice, Informant A gave high attention of environmentally friendly products, especially The Body Shop products. When she visited The Body Shop store, she was attracted by the pamphlet and tried to find out the information through the products.

There was only one pamphlet at that time and it was placed in the shelf with a bright color, simple words, and the picture of the product which was related with the campaign. Aside from the pamphlet, she brought back the empty bottles to participate in the Bring Back Our Bottle program. She got the customer points by exchanging the empty bottles.

\section{The effect of green marketing on The Body Shop's brand equity}

The practice of green marketing has positively influenced The Body Shop's brand equity (Yoo et al., 2000). The Body Shop brand has been well positioned in informants' minds (Aaker, 1996; Leone et al., 2006). The success of green marketing made The Body Shop distinct. The informants were loyal and satisfied with The Body Shop products. The informants had a good understanding about The Body Shop based on their experiences as long-term users of the products, as stated by Aaker (1996).

"Since the beginning, it [The Body Shop] has already go green, has become its attractiveness, the name of The Body Shop itself certainly create a mindset about, what to say, green marketing." Informant B

Informant B saw The Body Shop as a brand which always implies green practices. During her daily activities at home, she sometimes browsed The Body Shop news on the internet through mobile phone while she looked after her baby. The Body Shop news was delivered through The Body Shop's website, Instagram, and e-mail. 
In order to describe the green marketing's affection on The Body Shop's brand equity, this study referred to The Brand Equity Ten which suggested by Aaker (1996). It serves in the five core dimensions below.

\section{Loyalty}

Aaker (1996) stated that the market may consist of loyal buyers of a brand, brand switchers, and non-customers. In this current study, the informants were identified as the loyal buyers of a brand. In average, the informants have experienced The Body Shop products for more than five years continually. Based on Aaker's (1996) theory, the use duration of the products described the informants' loyalty to The Body Shop. The informants sensed their skin to besafe, healthy, and fresh. The results of using The Body Shop products were satisfied them. Thus, they are willing to pay the premium price of The Body Shop. Informant A expressed her willingness to pay the premium pricefor The Body Shop.

"... The price and the products quality are actually equal. There are a lot of [other] products with higher price without offering something natural. So, in my opinion, if the price is high but the products are totally safe, it is equal for me...." - Informant A

\section{Perceived quality and leadership}

As long-term users of The Body Shop, the informants were able to perceive the quality of The Body Shop products. They perceived that The Body Shop offers high quality products. It was unsurprising that The Body Shop served its products in premium price. The Body Shop offers their products in various ways. It collaborates with the happening environmental issues, the nation's welfare, or other social actions which were donated by The Body Shop. Although The Body Shop is innovative in serving their products, the consistency of the products was remained the same. Informant $\mathrm{C}$ was fascinated to the consistency of The Body Shop products since at the first time she knew The Body Shop brand.

"I have been used The Body Shop for ten years and there is one of my product which is used since the first time, even the smell is not changing."Informant C

\section{Brand association}

The personal benefits, such as skin suitability, and the environmental benefits, such as animal protection, have brought The Body Shop as a distinct brand. The informantsperceived that The Body Shop is distinct because of its green marketing practices. They saw that The Body Shop's environmentally friendly products can influence individual positively. The Body Shop brand has been associated with green products, which are harmless to the environment (Vazifehdoust et al., 2013; Awan \& Wamiq , 2016). According to Aaker (1996), the brand reflection as product is known as perceived value, while the brand reflection as individual's personality is known as brand personality. The Body Shop grows in both reflections of brand. Informant $D$ stated that beautiful is not necessarily harming the skin and the environment.

"Beautiful is not necessarily... not necessarily associated with chemical [ingredients]." - Informant D

\section{Brand awareness}

The informants valued The Body Shop as a brand which has high concern on environmental issue. The green products and the green programs of The Body Shop lead to the brand preference and loyalty. For instance, Informant E stated that The Body Shop founder has high sensitivity on the environment. The founder's sensitivity on the environment was brought throughout the brand and the products. It reveals the brand preference of The Body Shop itself.

"... Its [The Body Shop's] founder, the founder is also having e... great sensitivity on the environment. Thus, the brand image is brought by her [the founder]. The desired image has been brought into the products." - Informant $\mathrm{E}$

\section{Market behaviors measures}

Although the informants needed to travel outside Salatiga to reach the stores, they did not see the distance and time as the barriers. It represents the market behaviors of The Body Shop. It does not support Chan (2001) statement that the unavailability of the products decreases the customers' purchases. The informants were still visiting the stores, although they had to put much efforts to access The Body Shop through the 
malls in Semarang, Solo, and even other cities. For example:

"But because it [The Body Shop] is not available in Salatiga, e... I often go to Semarang, or to Solo. ..." - Informant C "... But I never see... it washardly ever to see Body Shop's counters are out of customers. ..." - Informant B

It shows that the location and time barrier, which have been stated by Young et al. (2000) and Awan and Wamiq (2016) cannot be applied on natural beauty product category, such as The Body Shop.

The informants' preferences for the brand showed that the high brand equity creates high engagement with the customers (Yoo et al., 2000)and loyalty (Chang \& Fong, 2010). Informant B, Informant $C$, and Informant D are highly engaged with The Body Shop brand.
"For me, it is good. And then, it is because... yeah it has already... it is suitable for me, I love Body Shop." - Informant B
"When talking about The Body Shop, it is about one thing: It is my favorite products, The Body Shop." - Informant C "... from those several choices (of brands), the most durable brand up to this time is The Body Shop." - Informant D

It supports Arseculeratne and Yazdanifard (2014), Chang and Chen (2014), and Nazari et al., (2015) who stated that green marketing raised the brand equity and the competitive advantage of the firm.

\section{The informants' decision to purchase The Body Shop products as green products}

The informants' first purchase on The Body Shop was supported by two factors, which are financial factor and situational factor. The informants' purchase green products are constructed by consumers' knowledge and beliefs (Chan R. Y., 2001; Vazifehdoust et al., 2013). The informants' characteristics were taking role behind the informants' knowledge and beliefs (Laroche et al., 2001; Gan et al., 2008). Their choices toward The Body Shop products were grounded by their concern on their adult skin, which need more treatment with environmentally friendly products. The financial availability of the informants are also important to fulfill their needs toward The
Body Shop products. It means that the studies of Laroche et al. (2001) and Gan et al. (2008) who suggested that income did not influence thegreen purchasing decision, are not supported by this study.

Not only income variable, this study found that the informants' occupation also influence the environmental concern in purchasing green products, as stated by Informant $A$ and Informant $\mathrm{E}$.

"E... from my job point of view, my job really supports the green environment."Informant A

"I have known Body Shop since a long time ago, e... because I used the products and becauseof business." Informant E

The occupation of Informant A and Informant $E$ in industrial field have allowed them to learn and respect the environment. Therefore, they chose products which are produced in responsibility and ethical, both for human and environment. The occupation field may construct the environmental motive in purchasing The Body Shop products. It supports the study of Do Paco and Raposo (2008) which stated that occupation was significantly influence the environmental concern in purchasing products.

The Body Shop green marketing grows as the characteristics of the brand. Thus, the green aspects such as environmentally friendly and Fair Trade practices were inserted as the informants' purchasing motives (Vazifehdoust et al., 2013). For example, Informant $\mathrm{E}$ placed the environmental motives as the first motive to purchase The Body Shop products.

"Fair Trade. Farmers." - Informant E

Although the answer is short, it gives the description on how the green practices can strongly influence the customers.

However, inserting the environmental motive on green purchasing decision does not necessarily mean that it is the first motive. Different with Informant $E$, the other four informants inserted the environmental motive as their second and third motive. As shown by Informant $A$ on her attention to the green pamphlet (Figure 2), she did not purchase the related products because it does not fit her. The suitability of the products is her main concern. The main motive in purchasing The Body Shop as the green products is their personal motive. Informant B and Informant C 
also stated that the products are suitable for their skin.

"Initially, it is suitable ..." - Informant B

"Oh... suitable, e... its consistency is good." - Informant C

This study supports the previous study by Ottman et al. (2006) which stated that the main reason of green purchasing decision is not necessarily about the environmental motive. The green products can offer more than the green advantage.

The products suitability, promo, discounts, and prestige were also stated as the purchasing motives of the informants. The price consideration indeed becomes the important aspect in purchasing green products, such as The Body Shop (Yoo et al., 2000; Gan et al., 2008; Young et al., 2010). Not only The Body Shop, Informant A was also willing to pay higher price for daily green products, such as organic vegetables, organic fruits, and organic rice. The observations toward Informant A support the findings of the studies of Laroche et al. (2001), Haytko and Matulich (2008), and Banyte et al. (2010) about the willingness to pay higher price for green products.

Figure 2 is grounded by the results of this study as a whole. The green marketing has influenced The Body Shop's brand equity positively. When the brand equity is achieved, the consumers are willing to pay the premium price and being loyal to the brand (Yoo, Donthu, \& Lee, 2000; Delafrooz, Taleghani, \& Nouri, 2014). It leads to the concern of environmental motive when they were deciding to purchase The Body Shop products.

The results of this study reveal that the green marketing and brand equity of The Body Shop should always be engaged in making the brand distinct and strong (Aaker, 1996). It indicates that the integration between products quality, brand, and high performance of The Body Shop (Sinnappan \& Rahman, 2011) drove the informants into their actual purchasing decisions. The association between green marketing and brand equity encourage the informants to insert environmental motive as their purchasing motive.

\section{CONCLUSION}

Applying green marketing inside the firm is important. Based on the results and discussions in previous section, this study found that the informants perceived The Body Shop's green marketing as a respectable action to reduce the negative impact of the firms' business activities. The eco-label appeared as the most visible green marketing tools which influenced the informants' environmental knowledge. Green marketing creates a value-added to The Body Shop's products which makes the brand distinct from others. The Body Shop's green marketing activities were settled in advanced, to invite the customers' participation.

The strong brand equity of The Body Shop was affected by its application of green marketing and the perception of its customers towards the green marketing practices. Achieving high brand equity was followed the positive integration among loyalty, perceived quality, awareness, brand association, and market behavior of the customers. The informants position The Body Shop on top of their minds among the other natural beauty products. The strong brand equity of The Body Shop has created the informants' emotional bonds. Although The Body Shop products served in premium price, the informants valued the given benefits by The Body Shop. Both green benefits and nongreen benefits were sensed by the informants. Subsequently, it creates the brand preference of the customers.

Figure 2.

Proposed model for green marketing, brand equity, and green purchasing decision

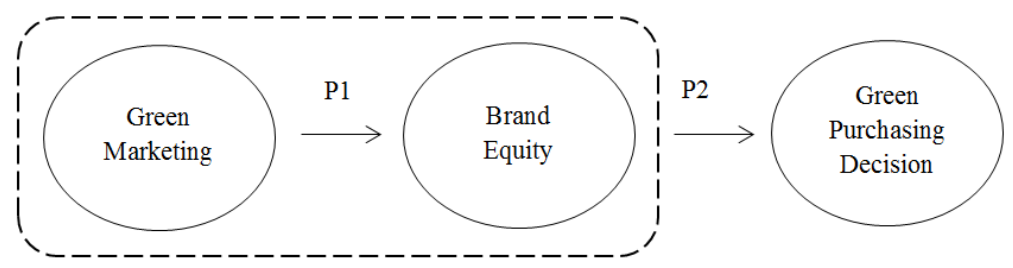


This study found that the informants' reasons on purchasing The Body Shop products were followed by the personal concern, environmental concern, economic concern, and social concern. The Body Shop's green attributes has encouraged the informants to purchase the products. However, the main reason to purchase The Body Shop products was affected by personal preference. The other motives which encourage the informants are promo, sale, discount, and the prestige on using The Body Shop. As a whole, the informants' purchases give the positive impacts both for human and environment. It described on why the informants decide to purchase The Body Shop rather than the regular beauty products.

\section{Managerial implication}

Understanding the customers' needs and wants are important in marketing application. This study has shown the importance of integrating the green marketing, brand equity, and green purchasing decision of The Body Shop's customers. The customers' perceptions of the firm are the impressions which lead to the final purchasing decision of the products. The customers' perceptions were valued by the way thegreen marketing actions of The Body Shop are delivered to the customers. The green marketing can be delivered effectively without indulgence advertisements, which may lead to the misperception of the customers. Although the informants have placed The Body Shop on top of their minds, The Body Shop must sustain their green marketing to maintain the brand engagement with the customers.

\section{Theoretical implication}

The qualitative method has allowed this study to explore the deeper understanding of The Body Shop's customers in personal. The results within this study both support and disrupt the previous studies. In answering the first and the second research questions, this study supports the previous studies related to green marketing(Laroche et al., 2001; Haytko \& Matulich, 2008; Banyte et al., 2010; Rahbar \& Wahid, 2011; Delafrooz et al., 2014) and brand equity(Aaker, 1996; Arseculeratne \& Yazdanifard, 2014; Chang \& Chen, 2014; Nazari et al., 2015). The results of the third research question related to green purchasing decision were shown some differences with the studies of Chan (2001),
Laroche et al. (2001), and Gan et al. (2008). On the other hand, it shows the similarity with the studies of Ottman et al. (2006) and Do Paço and Raposo (2008).Thus, these findings might enrich the existing theories about the relations among green marketing, brand equity, and green purchasing decision related with beauty product category.

\section{Limitation}

First, this study claimed to have its limitations related to the informants' statements. Their perceptions about The Body Shop's green marketing were positive because they got the green messages from The Body Shop. They did not truly understand on the actual production process of The Body Shop products. In fact, this study found that four informants placed their personal motive as the strongest purchasing motive. Thus, not all the informants surely concern with the surrounding environment. The misinformation of this study was happened because there was no definite question related to their environment concern during the interviews. The second limitation of this study isthis study did not insert the educational background of the informants. It may induce the informants' beliefs on The Body Shop's green marketing, brand equity, and green purchasing decision.

\section{Suggestion and future research agenda}

Due to its limitation, this study suggests that the definite question related to the informants' environmental concern are need to be prepared before the other questions about The Body Shop. The informants' personal statements related to the environmental concern will be the highlight of the results and discussion in this study. Thus, there is no misinformation on the informants' perception towards The Body Shop's green marketing. Then, the specific the informants' educational background can be considered to reveal a deeper understanding of the informants. Related with green marketing, brand equity, and green marketing decision, this study has proposed two variable models (Figure 1 and Figure 2). However, those models need to be tested. The quantitative study allows the models are tested within more customers of The Body Shop. 


\section{REFERENCES}

Aaker, D. A. (1996). Measuring Brand Equity Across Products and Markets. California Management Review, 38(3), 102-120.

Arseculeratne, D., \& Yazdanifard, R. (2014). How Green Marketing Can Create a Sustainable Competitive Advantage for a Business. International Business Research, 7(1), 130-137.

Awan, A. G., \& Wamiq , S. (2016). Relationship between environmental awareness and. Science International, 2959-2963.

Banyte, J., Brazioniene, L., \& Gadeikiene, A. (2010). Expression of Green Marketing Developing the Conception of Corporate Social Responsibility. Inzinerine Ekonomika-Engineering Economics, 21(5), 550-560.

Bonroy, O., \& Constantos, C. (2008). On the use of labels in credence goods markets. Journal Regulation Economy, 33, 237252.

Boztepe, A. (2012). Green Marketing and Its Impact on Consumer Buying Behavior. European Journal of Economic and Political Studies, 5(1), 5-21.

Buil, I., de Chernatony, L., \& Martinez, E. (2013). Examining the role of advertising and sales promotions in brand equity creation. Journal of Business Research, 115-122.

Carrigan, M., \& Attalla, A. (2001). The Myth of Ethical Consumer - Do Ethics Matter in Purchase Behavior? Journal of Consumer Marketing, 18(7), 560-578.

Carrington, M. J., Neville, B. A., \& Whitwell, G. J. (2010). Why Ethical Consumers Don't Walk Their Talk: Towards a Framework for Understanding the Gap Between the Ethical Purchase Intentions and Actual Buying Behaviour of Ethically Minded Consumers. Journal of Business Ethics, 97, 139-158.

Carrington, M. J., Neville, B. A., \& Whitwell, G. J. (2014). Lost in translation: Exploring the ethical consumer intention-behavior gap. Journal of Business Research, 67, 27592767.

Chan, K., \& Han, X. (2014). Effectiveness of environmental advertising for hotels. Services Marketing Quarterly, 35(4), 289303.

Chan, R. Y. (2001). Determinants of Chinese Consumers' Green Purchase Behavior. Psychology \& Marketing, 18(4), 389-413.

Chang, C.-H., \& Chen, Y.-S. (2014). Managing green brand equity: the perspective of perceived risk theory. Quality \& Quantity, 48(3), 1753-1768.

Chang, N.-J., \& Fong, C.-M. (2010). Green product quality, green corporate image, green customer satisfaction, and green customer loyalty. African Journal of Business Management, 4(13), 28362844.

Delafrooz, N., Taleghani, M., \& Nouri, B. (2014). Effect of green marketing on consumer purchase behavior. QScience Connect, 5.

do Paço, A., \& Raposo, M. (2009). "Green" segmentation: an application to the Portuguese consumer market. Marketing Intelligence \& Planning, 27(3), 364-379.

D'Souza, C., Taghian, M., \& Lamb, P. (2006). An empirical study on the influence of environmental labels on consumers. Corporate communications: an international journal, 11(2), 162-173.

Gan, C., Wee, H. Y., Ozanne, L., \& Kao, T.-H. (2008). Consumers' purchasing behavior towards green products in New Zealand. Innovative Marketing, 4(1), 94-102.

Haytko, D. L., \& Matulich, E. (2008). Green Advertising and Environmentally Responsible Consumer Behaviors: Linkages Examined. Journal of Management and Marketing Research, 1(2), 2-11.

Iwan, C. Y. (2013). Pengaruh Sikap terhadap Green Advertising pada Brand Image The Body Shop antara Konsumen Domestik dan Asing. Jurnal JIBEKA, 7(3), 5-10.

Kaufmann, H. R., Panni, M. F., \& Orphanidou, Y. (2012). Factors affecting consumers' green purchasing behavior: an integrated conceptual framework. Amfiteatru Economic, 14(31), 50-69.

Laroche, M., Bergeron, J., \& Barbaro-Forleo, G. (2001). Targeting consumers who are willing to pay more for environmentally friendly products. Journal of Consumer Marketing, 18(6), 503-520.

Leone, R. P., Rao, V. R., Keller, K. L., Luo, A. M., McAlister, L., \& Srivastava, R. (2006). Linking Brand Equity to Customer Equity. Journal of Service Research, 9(2), 125138.

Leonidou, L. C., Leonidou, C. N., Hadjimarcou, J. S., \& Lytovchenko, I. (2014). Assesing the greenness of environmental advertising claims made by multinational industrial firms. Industrial Marketing Management, 43(4), 671-684.

Leonidou, L. C., Leonidou, C., Palihaeadana, D., \& Hultman, M. (2011). Evaluating the green 
advertising practices of international firms: a trend analysis. International Marketing Review, 28(1), 6-33.

Maheshwari, S. (2014). Awareness of Green Marketing and Its Influences on Buying Behavior of Consumer:. AIMA Journal of Management \& Research, 8(1).

Malhotra, N., \& Malhotra, P. (2015). Importance of Brand Equity. International Journal of Management and Commerce Innovations, 3(1), 366-369.

Marshall, M. N. (1996). Sampling for qualitative research. Family Practice, 13(6), 522525.

Moleong, L. J. (2010). Metodologi Penelitian Kualitatif. Bandung: PT Remaja Rosdakarya.

Nazari, E., Ghasemi, B., \& Saeidi, S. S. (2015). Explain The Relationship Between Green Brand Image, Green Satisfaction and Green Trust and Factors Affecting on Green Brand Equity. Bulletin of The Georgian National Academy Sciences, 9(1), 487-494.

Orsato, R. J. (2006). Competitive Environmental Strategies: when does it pay to be green? California Management Review, 48(2), 127-143.

Ottman, J. A., Stafford, E. R., \& Hartman, C. L. (2006). Avoiding Green Marketing Myopia. Environment, 48(5), 22-36.

Peattie, K., \& Crane, A. (2005). Emerald Article: Green marketing: legend, myth, farce or prophesy? Qualitative Market Research: An International Journal, 8(4), 357-370.

Polonsky, M. J. (1994). An Introduction To Green Marketing. Electronic Green Journal, 1(2), 1-10.

Rahbar, E., \& Wahid, N. A. (2011). Investigation of green marketing tools' effect on consumers' purchase behavior. Business Strategy Series, 12(2), 73-83.

Rakhsha, R., \& Majidazar, M. (2011). Evaluation of Effectiveness Ofgreen Marketing Mix on Consumer Satisfasction and Loyalty: (Case Study: The East Azarbaijan Pegah Dairy Company in Tabriz, Iran). MiddleEast Journal of Scientific Research, 10(6), 755-763.

Rashid, N. R. (2009). Awareness of Eco-label in Malaysia's Green Marketing Initiative.
International Journal of Business and Management, 4(8), 132-141.

Roddick, A. (2013). Business as Unusual. Jakarta: PT Gramedia Pustaka Utama.

Shaw, D., Grehan, E., Shiu, E., Hassan, L., \& Thomson, J. (2005). An exploration of values in ethical consumer decision making. Journal of Consumer Behaviour, 4(3), 185-200.

Sinnappan, P., \& Rahman, A. A. (2011). Antecedents of Green Purchasing BEhavior among Malaysian Consumers. International Business Management, 5(3), 129-139.

Sulistyowati. (n.d.). Kementrian lingkungan hidup republik indonesia. Retrieved January 10, 2017, from www.menlh.go.id: http://www.menlh.go.id/greeningbusiness/

The Body Shop. (2015). Building for the future: our values performance 2014/2015 \& our new commitment.

Todd, A. M. (2004). The aesthetic turn in green marketing: Environmental consumer ethics of natural personal care products. Ethics and the Environment, 86-102.

Uusitalo, O., \& Oksanen, R. (2004). Ethical consumerism: a view from Finland. International Journal of Consumer Studies, 28(3), 214-221.

Vazifehdoust, H., Taleghani, M., Esmaeilpour, F., Nazari, K., \& Khadang, M. (2013). Purchasing green to become greener: Factors influence consumers' green purchasing behavior. Management Science Letter, 3, 2489-2500.

Wood, L. (2000). Brands and brand equity: definition and management. Management Decision, 38(9), 662-669.

Yoo, B., Donthu, N., \& Lee, S. (2000). An Examination of Selected Marketing Mix Elements and Brand Equity. Journal of the Academy of Marketing Science, 28(2), 195-211.

Young, W., Hwang, K., McDonald, S., \& Oates, C. J. (2010). Sustainable consumption: green consumer behaviour when purchasing products. The Open Access Institutional Repository at Robert Gordon University, 18(1), 20-31. 